\title{
PERKAWINAN KATOLIK SEBAGAI JALAN MENUJU KESUCIAN
}

\author{
Oleh: Theo Uheng Koban Uer
}

\begin{abstract}
Abstrak:
Masalah yang menjadi fokus penulisan artikel ini adalah upaya apakah yang perlu dilakukan agar Gereja domestik yang menjadi nuklir Gereja universal semakin berkualitas dalam menggapai kesucian dan cara-cara manakah yang perlu dilakukan agar Gereja domestik yang terus berlangkah menuju kesucian semakin berkualitas dalam kehidupan berkeluarga. Tujuan penulisan adalah untuk menemukan dan mendeskripsikan upayaupaya yang perlu dilakukan agar Gereja domestik semakin mantap berjalan menuju kesucian dan menemukan cara yang tepat dan efektif dalam perjalanannya menuju kesucian hidup berkeluarga. Metode yang dipakai adalah membaca, merefleksi berbagai sumber bacaan dan informasi sebagai data untuk dianalisis. Dan hasil yang dicapai adalah menemukan dan mendeskripsikan dimensi-dimensi perkawinan katolik dan hidup keluarga sebagai wadah dan jalan menuju kesucian perkawinan Katolik.
\end{abstract}

Kata-kata kunci: sakramen perkawinan, Gereja domestik, keempat karakter Gereja, komunitas kasih, relasi dalam keluarga.

\section{PENDAHULUAN}

\subsection{Konteks Penulisan}

$\mathrm{P}$ erkawinan Katolik sebagai sakramen merupakan jalan yang menyalurkan atau menyampaikan rahmat dan kasih Tuhan secara nyata. Melalui sakramen tersebut, Allah mengirimkan Roh Kudus-Nya untuk menyembuhkan, memberi makan, dan meneguhkan Gereja-Nya. Kristus sendiri telah menjanjikan Penghibur yakni 'Paraclitus'. Kristus bersabda, "Aku tidak akan meninggalkan kamu sebagai yatim piatu. Aku datang kembali kepadamu." (Yoh 14: 18). Janji Kristus ini sungguh telah, sedang, dan terus terpenuhi melalui ketujuh sakramen Gereja Katolik termasuk Sakramen Perkawinan. Kristus juga telah bersabda, "Akulah jalan kebenaran dan hidup. Tidak ada seorangpun yang datang kepada Bapa, kalau tidak melalui Aku" (Yoh 14: 6).

Sebagian besar dari umat Allah terpanggil untuk kehidupan berrumah tangga atau membentuk Gereja domestik dan dalam istilah Konsili Vatikan II 'Ecclesia domestica' atau Gereja Rumah tangga. Paus Yohanes Paulus I, selama pelayanannya yang amat singkat pada takhta Petrus, menunjuk Keluarga Kristiani sebagai Gereja domestik. Paus Yohanes Paulus I dalam suratnya yang ditujukan kepada sekelompok Uskup Amerika Serikat, berbicara tentang kehidupan keluarga. "Keluarga kristiani adalah sedemikian penting, serta perannya sedemikian mendasar di dalam mengubah dunia dan membangun Kerajaan Allah, yang oleh Konsili Vatikan II disebut 'Gereja domestik'. Marilah kita tak lelah-lelahnya menyatakan keluarga sebagai suatu persekutuan cinta kasih; cinta kasih suami-istri mempersatukan pasangan suami-istri dan bersifat prokreatif terhadap kehidupan baru. Ini mencerminkan cinta kasih ilahi, dikomunikasikan, dan menurut istilah Gaudium et Spes, sebenarnya merupakan suatu sharing dalam perjanjian cinta Kristus dan Gereja-Nya ...Kesucian keluarga kristiani sungguh merupakan suatu alat yang sangat tepat untuk menghasilkan pembaruan Gereja yang sangat diinginkan oleh Konsili Vatikan II. Melalui doa keluarga, 'ecclesia domestica' menjadi suatu realitas yang efektif dan 
membawa kepada perubahan dunia. Marilah kita melakukan segala sesuatu yang dapat kita lakukan bagi keluarga-keluarga kristiani sehingga umat kita dapat memenuhi panggilan agung mereka dalam kegembiraan kristiani serta dapat bersama-sama secara akrab dan efektif menanggung misi keselamatan Gereja, Misi keselamatan Kristus."1

Gereja universal juga menjadi model Gereja domestik. Artinya sebagaimana diamanatkan dalam Konsili-Konsili sebelumnya seperti Konsili Nicea dan Konstantinopel bahwa baik Gereja universal maupun Gereja domestik merupakan suatu keutuhan yang berkarakter satu, kudus, katolik, dan apostolik. Satu berarti memiliki kesatuan dalam iman akan Kristus karena Kristus hadir sebagai mempelai Gereja. Oleh sebab itu kasih Kristus adalah dasar hidup suami-istri yang telah menjadi satu dalam Sakramen Perkawinan. "Apa yang dipersatukan Allah janganlah diceraikan manusia.” (Mat 19: 5).

Relasi kesatuan yang dilakukan suami-istri melalui proses prokreasi adalah kudus karena bersifat sakramental. Allah sendirilah yang memberikan kesuburan dan memberikan nafas kehidupan kepada anak yang dilahirkan dan sebagai mitra Allah, orang tuanya menumbuhkembangkan anak-anak yang dilahirkan dalam kasih Kristus berkat Sakramen Baptis. Sebaliknya anak-anak tersebut harus taat dan kasih akan bapak-ibunya agar memperoleh kesejahteraan dalam hidupnya. Dan dengan berbuat demikian bapak-ibu serta anak-anaknya membentuk sebuah komunitas iman yang menyelamatkan. Dan setiap anggota keluarga hidup dalam kesetaraan, terlibat dalam kasih dan saling menghargai sebab mereka adalah citra Allah. Mereka adalah keluarga katolik. Dan selanjutnya dengan melaksanakan amanat Kasih Tuhan mereka menjadi pewarta Firman Allah sehingga Gereja domestika melaksanakan fungsi dan peran keapostolikannya. Inilah misi Gereja yang berkarakter satu, kudus, katolik, dan apostolik.

Gagasan pokok Konsili Vatikan II dalam Gaudium et Spes bahwa Gereja domestika merupakan Komunitas Kasih, Komunitas Hidup, dan komunitas Keselamatan. Dan dalam proses pembentukan komunitas tersebut mereka harus setia menjalankan peran dan fungsinya sebagai imam, nabi, dan raja. "Kamulah bangsa yang terpilih, imamat yang rajani, bangsa yang kudus, umat kepunyaan Allah sendiri, supaya kamu memberitakan perbuatan-perbuatan yang besar dari Dia, yang telah memanggil kamu keluar dari kegelapan kepada terang-Nya yang ajaib" (1 Ptr 2:9). Dan dalam melaksanakan Tritugas Kristus tersebut Gereja domestik akan terus berlangkah menuju kesuciannya sehingga menjadi Gereja domestik yang semakin berkualitas.

\subsection{Fokus Penelitian}

Bertumpu pada sekilas pembahasan tentang Gereja domestik yang satu, kudus, katolik,dan apostolik yang sekaligus sebagai komunitas kasih, komunitas hidup, dan komunitas keselamatan; yang menjalankan fungsi dan perannya sebagai nabi, imam, dan raja, maka muncullah masalah pokok yang menjadi fokus penulisan artikel sebagai berikut.

(a) Upaya apakah yang perlu dilakukan agar Gereja domestik yang menjadi nuklir Gereja sejagat semakin berkualitas dalam menggapai kesuciannya.

(b) Manakah cara-cara efektif yang perlu dilakukan agar Gereja Rumah tangga yang terus berlangkah menuju kesucian perkawinan dan hidup keluarga semakin berkualitas.

\footnotetext{
${ }^{1}$ Maurice Eminyan, Teologi Keluarga (Yogyakarta: Kanisius, 2001), hlm. 212-213.
} 


\subsection{Tujuan Penulisan}

(a) Menemukan dan mendeskripsikan upaya yang perlu dilakukan agar Gereja domestik semakin mantap menjadi wadah dan jalan menuju kepada kesuciannya

(b) Menemukan dan mendeskripsikan cara-cara yang tepat agar Gereja domestik terus menata perjalanannya menuju kesucian hidup perkawinan dan hidup keluarga.

\section{PERKAWINAN KATOLIK SEBAGAI BENTUKAN AWAL GEREJA DOMESTIK}

\subsection{Dasar Biblis Perkawinan Katolik}

Kitab Kejadian melukiskan Allah menciptakan manusia sebagai berikut. "Baiklah Kita menjadikan manusia menurut gambar dan rupa Kita, supaya mereka berkuasa atas ikan-ikan di laut dan burung-burung di udara dan atas ternak dan atas seluruh bumi dan atas segala binatang melata yang merayap di bumi." Allah menciptakan manusia itu menurut gambar-Nya Dia; laki-laki dan perempuan diciptakan-Nya mereka. Allah memberkati mereka, lalu Allah berfirman kepada mereka: "Beranak cuculah dan bertambah banyak; penuhilah bumi dan taklukkanlah itu, berkuasalah atas ikan-ikan di laut dan burung-burung di udara dan atas segala binatang yang merayap di bumi” (Kej 1 : 27 28). Tuhan Allah berfirman, "Tidak baik kalau manusia itu seorang diri saja. Aku akan menjadikan penolong baginya yang sepadan dengan dia...Lalu Tuhan Allah membuat manusia itu tidur nyenyak, ketika ia tidur, Tuhan Allah mengambil salah satu tulang rusuk dari padanya, lalu menutup tempat itu dengan daging. Dan dari rusuk yang diambil Tuhan Allah dari manusia itu, dibangun-Nyalah seorang perempuan, lalu dibawa-Nya kepada manusia itu. Lalu berkatalah manusia itu: "Inilah dia, tulang dari tulangku dan daging dari dagingku. Ia akan dinamai perempuan sebab ia diambil dari laki-laki." Sebab itu seorang laki-laki akan meninggalkan ayahnya dan ibunya dan bersatu dengan istrinya sehingga keduanya menjadi satu daging (Kej 2:18,21-24).

Melalui kisah penciptaan manusia ini dapatlah dikatakan beberapa hal berikut. Pertama, Allah menciptakan manusia berpasangan, memberkati keduanya. Kedua, Allah sendiri hadir dengan Roh-Nya dalam proses penciptaan itu. Ketiga, Allah tak perlu menciptakan manusia baru lagi tetapi mengikutsertakan pria dan wanita sebagai suami-istri untuk menjadi procreator "pencipta bersama Allah." Mereka menjadi rekan sekerja melalui tindakan cinta mereka, bersama dengan tindakan Allah yang sangat indah: penerusan hidup kepada manusia. ${ }^{2}$ Demikianlah Allah menciptakan keluarga pertama dan sekaligus menghadirkan Roh-Nya dalam proses penciptaan. Suami-istri dan bapak-ibu menjadi rekan sekerja Allah yang sangat unik dan indah: yakni penerusan hidup kepada manusia lain.

Selanjutnya dalam Perjanjian Baru, Kristus sebagai Putera Allah meneguhkan dan menjadikan perkawinan sebagai sakramen. Dalam peristiwa perkawinan di Kana, Kristus mengubah air menjadi anggur, "sebagai pertama dari tanda-tanda-Nya dan dengan itu Ia telah menyatakan kemuliaan-Nya dan murid-murid-Nya percaya kepada-Nya" (Yoh 2: 11). Kemudian Yesus menegaskan keutuhan dan persatuan dalam pernikahan sebagai sakramen:

\footnotetext{
${ }^{2}$ Ibid., hlm. 29.
} 
Tidakkah kamu baca, bahwa Ia yang menciptakan manusia sejak semula menjadikan mereka laki-laki dan perempuan? Dan firman-Nya sebab itu laki-laki akan meninggalkan ayah dan ibunya dan bersatu dengan istrinya sehingga keduanya itu menjadi satu daging. Demikianlah mereka bukan lagi dua melainkan satu. Karena itu apa yang telah dipersatukan Allah tidak boleh diceraikan manusia (Mat 19: 4-7).

Dan selanjutnya Rasul Paulus dalam suratnya kepada umatnya di Efesus menyatakan tentang kasih Kristus adalah dasar hidup suami-istri. Bahkan ditegaskannya bahwa hubungan suami-istri itu sebagai sharing relasi cinta Allah dengan umat-Nya atau cinta Allah dengan manusia. Rasul menegaskan makna yang lebih dalam "Rahasia ini besar tetapi yang aku maksudkan ialah hubungan Kristus dengan Jemaat” (Ef 5: 12).

Konsili Vatikan II dalam Gaudium et Spes menegaskan bahwa perkawinan dan hidup keluarga merupakan bentukan Gereja domestik atau Gereja Rumah tangga yang menjadi model Gereja sejagat atau Gereja universal dengan sifat dan ciri yang khas yakni satu, kudus, katolik, dan apostolik. Sifat tersebut beroleh dasar kebenarannya dalam rencana yang diwahyukan Allah. Dan salah satu sifat 'tak terbatalkan' oleh alasan apapun karena "yang dipersatukan Allah tak boleh diceraikan manusia" merupakan tuntutan cinta yang mutlak setia, kasih Allah terhadap manusia, dan kasih Tuhan Yesus terhadap GerejaNya.

\subsection{Perkawinan Katolik sebagai Jalan Menuju Kesucian}

Sejak awal mula setelah menciptakan manusia secara berpasangan, Allah berfirman kepada mereka, "Beranak cuculah dan bertambah banyak, penuhilah bumi dan taklukkanlah itu, berkuasalah atas ikan-ikan di laut dan burung-burung di udara dan atas segala binatang yang merayap di bumi." (Kej 1: 27). Firman ini menunjukkan bahwa manusia dipanggil untuk menjadi mitra Allah sebagai pencipta. Atau manusia dipanggil dan dikuduskan menjadi sakramen satu terhadap yang lain, menjadi procreator, yakni pencipta bersama Allah untuk membentuk Gereja domestik. Dan serentak dengan itu melahirkan anak, menumbuhkembangkan hidup mereka serta pendidikannya.

Selanjutnya melalui ayat yang sama, Allah memanggil manusia untuk memperhatikan serta merawat lingkungan hidupnya. Firman-Nya, "taklukkanlah dan kuasailah" (Kej 1: 27). Itu berarti Allah mengijinkan manusia secara khusus ikut serta dalam seluruh karya penciptaan-Nya sendiri. Dengan demikian merusak lingkungan hidup atau dengan semena-mena manusia melakukan pengrusakan lingkungan hidup, mereka melawan perintah Tuhan.

Perkawinan Katolik yang bersifat sakramental perlu dilakukan dan dihidupsuburkan oleh suami-istri atas dasar cinta. Mencintai adalah sebuah keputusan. Cinta suami-istri dalam hidup perkawinan menjadi gambar cinta Allah. Ketika pasangan suami-istri mengabaikan cinta kasih satu sama lain dan mencederai cinta bagi anakanaknya yang dilahirkannya, maka hal ini akan mendatangkan banyak masalah. Pada umumnya akar dari berbagai masalah yang muncul dalam kehidupan keluarga adalah relasi seksual. 


\section{Paus Yohanes Paulus II dalam Anjuran Apostolik Familiaris Consortio menyebutkan:}

Seksualitas yang bagi pria maupun wanita merupakan upaya untuk saling menyerahkan diri melalui tindakan yang khas dan eksklusif bagi suami-istri, sama sekali tidak melulu bersifat biologis melainkan menyangkut kenyataan pribadi manusia yang paling inti. Seksualitas hanya diwujudkan secara sungguh manusiawi bila merupakan suatu unsur integral dalam cinta kasih, yakni bila pria dan wanita saling menyerahkan diri sepenuhnya seumur hidup. ${ }^{3}$

Amanat ini perlu diperhatikan dengan sungguh-sungguh sebab pria dan wanita memiliki gaya kepribadian yang berbeda-beda, Namun tindakan tersebut yang dilakukan merupakan aktivitas dalam jalan menuju kesucian. Bila pria dan wanita saling menyerahkan diri sepenuhnya atau secara total seumur hidupnya maka keduanya menjadi pasangan sakramental satu sama lain yang sedang berjalan menuju kepada kesucian. Demikian pula perbuatan-perbuatan lain serta karya misi Gereja dan Kristus sendiri. Sebagai anggota Gereja domestik bapak-ibu membesarkan dan mendidik anak-anaknya dengan penuh cinta. Tindakan inipun dijalankan menuju ke kesucian. Pendek kata segala upaya dan perbuatan yang dijalankan oleh setiap anggota keluarga dengan penuh kasih demi cinta Kristus sendiri maka perbuatan-perbuatan tersebut, tetap dan senantiasa menjadi jalan menuju ke kesucian. Pendeknya, perkawinan katolik dan hidup keluarga kristiani yang bersifat sakramental, yang malaksanakan misinya dalam relasi cinta kasih Allah dan manusia akan selalu berjalan menuju kesucian.

\section{MEMBANGUN KOMUNITAS CINTA, HIDUP DAN KESELAMATAN}

\subsection{Keluarga Sebagai Komunitas Cinta}

Maurice Eminyan memaparkan tentang gagasan-gagasan yang dikemukakan dalam Konsili Vatikan II khusus dalam Gaudium et Spes dan Familiaris Concortio oleh Paus Yohens Paulus II tentang panggilan hidup keluarga yang sedang mengalami krisis nilai yang sungguh-sungguh mengancam hidup manusia.

Berdasarkan pengalaman pendampingan keluarga dan refleksi teologis yang sistematis tentang keluarga kristiani, pengarang menulis mengenai keluarga sebagai komunitas cinta kasih, komunitas hidup, dan komunitas keselamatan. Karena setiap keluarga sejati dan bahagia merupakan suatu komunitas yang berlandaskan cinta kasih. Dan tak ada cinta kasih yang sejati dalam suatu keluarga tanpa ada kehidupan di dalamnya. Jika satu keluarga mewujudkan komunitas cinta kasih dan hidup itu berarti juga mewujudkan suatu komunitas rahmat, diberi arti buah rahmat ilahi. Semua umat manusia tanpa kecuali diberikan kemungkinan, pada umumnya, melalui cara yang cukup tersembunyi dari pengetahuan kita untuk mengenal dan mencintai Allah dan oleh karena itu menerima Roh Allah melalui Yesus Kristus Penyelamat kita. ${ }^{4}$

Dengan demikian bertumpu pada gagasan pastoral keluarga yang diamanatkan oleh Kitab Suci, Pesan para Rasul dan Bapa-Bapa Gereja, dilegitimasikan oleh Konsili Vatikan II, dan peneguhan dari surat-surat Apostolik oleh Paus Paulus IV, Paus Yohanes Paulus I, serta Paus Yohnes Palus II dalam Anjuran Apostolik Familiaris Concortio, maka perlu secara tetap dan berkesinambungan membangun Gereja domestik yang penuh cinta kasih, hidup, dan keselamatan.

\footnotetext{
${ }^{3}$ Ibid., hlm. 33.

${ }^{4}$ Ibid., hlm. 20.
} 
Dan secara garis besar, penulis hanya menyajikan sekilas makna ketiga komunitas tersebut yang menjadi wadah atau tumpuan dalam perjalanan hidup perkawinan katolik menuju kesuciannya.

\subsection{Makna Komunitas Cinta dalam Hidup Keluarga}

Makna teologis dari komunitas cinta kasih adalah mewujudkan komunitas tersebut menurut gambar dan citra Allah agar menjadi komunitas Trinitaris. Ini berarti pria dan wanita yang dipersatukan Allah dalam sakramen Perkawinan Katolik melalui rekan sekerja Allah melalui tindakan cinta mereka; bersama dengan tindakan Allah sebagai penerusan hidup kepada manusia lain. Dengan demikian menjadi cermin Trinitaris dalam Kristus dan Gereja-Nya (bdk Ef 5: 22-32).

Oleh sebab itu sebagaimana ditegaskan oleh Paus Paulus VI dalam ensiklik Humanae Vitae tentang ketiga ciri khas cinta perkawinan katolik sebagai berikut. (a) cinta perkawinan merupakan cinta yang sepenuhnya manusiawi yang merupakan persenyawaan antara perasaan dan roh antara kedua insan yang saling mencintai sehingga suami istri bersama-sama mencapai kepenuhan manusiawinya. (b) Cinta yang ada pada suami-istri yang membentuk keluarga adalah berciri totalitas. Artinya, pasangan yang saling mencintai memberi dirinya secara penuh karena keduanya sungguh-sungguh bermurah hati untuk memperkaya diri dan menghidupsuburkan cinta antar satu sama lain. (c) Ciri yang ketiga adalah kesetiaan. Artinya, cinta perkawinan itu berciri setia dan eksklusif. Suami bagi seorang istri adalah suami yang satu-satunya, dan istri bagi seorang suami adalah yang satu-satunya. Dan cinta ini berlangsung sampai ajal. Inilah janji kesetiaan antara pasangan suami-istri yang membentuk Gereja domestic. ${ }^{5}$

Ketiga kualitas cinta ini menggambarkan secara nyata bagaimana cinta suami-istri yang diungkapkan secara manusiawi namun Roh Kristus sendiri yang menjadikan cinta pasangan suami-istri semakin berkualitas menjadi cinta Bapa, Putera, dan Roh Kudus. Dan cinta itu terus bertumbuh dan berkembang dalam Kristus dan Gereja-Nya. Cinta Trinitaris yang tampak nyata dalam Cinta Keluarga Kudus yang tersembunyi di Nasareth bagi banyak orang namun menjadi model bagi cinta keluarga Kristen dalam Gereja sejagat.

\subsection{Makna Komunitas Hidup dalam Kehidupan Keluarga}

Inti pesan teologis dalam makna komunitas hidup adalah bahwa setiap pribadi yang hidup dalam komunitas ini harus bertumbuh bersama, bahwa komunitas ini menghadirkan anggota komunitas baru yakni anak-anak, serta mendidik putra-putrinya untuk menjadi anggota umat Allah yang baru melalui sakramen Baptis dan sakramen-sakramen lainnya. Bertumbuh bersama juga berarti setiap penghuni rumah tangga saling menghargai dan dihargai, saling melibatkan dan dilibatkan. Semua kegiatan yang dilakukan dalam bertumbuh bersama atas dasar cinta sejati yang diwujudkan dalam melayani satu terhadap yang lain.

Bertumbuh bersama juga bermakna melalui cinta kepasutrian yang khas sifat-sifat atau gaya kepribadian masing-masing dapat berubah dan mempengaruhi satu sama lain ke arah yang menyenangkan dan menggembirakan. Pendeknya cinta kasih yang penuh dengan kegembiraan adalah cinta kasih pada tingkat hidup yang lebih tinggi dan sungguh berkualitas dalam kebersamaan hidup. Kehidupan keluarga semacam ini menciptakan lingkungan yang baik bagi pengasuhan yang sehat bagi anak-anak.

Melalui cinta kesuami-istrian yang saling memberi dan menerima bukan saja menumbuhkembangkan kepribadian ke arah yang lebih sehat tetapi lebih dari berkat Kasih

\footnotetext{
${ }^{5}$ Ibid. hlm. 25-83.
} 
Allah akan istri yang akan mengandung, melahirkan kehidupan baru sehingga semakin bertumbuh kegembiraan dalam keluarga. Anak-anak akan bertumbuh sehat atas asuhan bapak-ibu yang penuh semangat sebagaimana Kristus mencintai Gereja-Nya.

\subsection{Makna Komunitas Keselamatan}

Secara singkat dapatlah dikatakan bahwa keluarga atau Gereja rumah tangga Ecclesia domestica di mana sakramen perkawinan merupakan sakramen tetap bagi pasangan suami-istri yang hidup dalam Gereja domestik yang mempunyai sifat-sifat yang sama dengan yang diemban Gereja sejagat melaksanakan Tri-tugas Kristus sebagai imam, nabi, dan raja. Rasul Petrus dalam suratnya yang pertama menulis, "Kamulah bangsa yang terpilih, imamat yang rajawi, bangsa yang kudus, umat kepunyaan Allah sendiri supaya kamu memberitakan perbuatan-perbuatan yang besar dari Dia yang telah memanggil kamu keluar dari kegelapan kepada terang-Nya yang ajaib" (1Ptr, 2: 9).

Dengan demikian dapatlah dikatakan keluarga Kristen ikut menghayati kehidupan dan misi Gereja yang mendengarkan Sabda Allah dengan khidmat serta mewartakannya penuh kepercayaan. Begitu keluarga Kristen menjalankan pesan kenabiannya dengan menyambut serta menyiarkan Sabda Allah. Keluarga dari hari ke hari makin berkembang sebagai persekutuan yang beriman dan mewartakan Injil. Demikianlah pernyataan Paus Yohanes Paulus II dalam Familiaris Consortio.

Selanjutnya Paus Yohanes Paulus II dalam amanat yang sama bahwa peran imamat keluarga terutama diaktifkan melalui sakramen-sakramen. Misalnya, menjelang anaknya dibaptis mereka mempersiapkan diri untuk menyongsong peristiwa penerimaan sakramen Baptis bagi anaknya. Demikian pula ketika putera-puterinya menerima Sakramen Ekaristi atau sakramen-sakramen lainnya. Tindakan-tindakan tersebut merupakan apresiasi imamat keluarga. Dan akhirnya ketika pasangan tersebut menerima Sakramen Perkawinan untuk membentuk keluarga Kristen atau Gereja domestika. Mereka memainkan peranan yang sangat penting untuk memenuhi semua tuntutan dalam menjalankan kehidupannya sebagai Gereja domestik. Sebagai Gereja domestik yang menjadi model Gereja universal, mereka harus taat pada ajaran Rasul yakni tetap memelihara kesatuan, saling menguduskan satu sama lain, menjaga dan memelihara kesetaraan antar setiap anggota dan serentak dengan itu menyebarkan Keraajaan Allah dan menyerukan pertobatan mulai dari dirinya sendiri dan menjangkau seluruh umat Allah.

Melalui tindakan dan perannya sebagai nabi, imam dan raja sesungguhnya Gereja domestik sedang dan senantiasa menapaki jalan menuju kesucian. Dan perlu tetap menyatukan diri dengan Kristus sang Penyelamat bersama dengan keluarga besar Gereja sejagat agar semakin hari semakin menjadi Komunitas Keselamatan. ${ }^{6}$

Membangun komunitas Cinta kasih, Komunitas Hidup dan Komunitas Keselamatan merupakan suatu tuntutan yang tidak mudah terpenuhi. Namun hal ini akan berhasil apabila Keluarga Kristen senantiasa membangun komunikasi Cinta antara sesama, bersama Allah Bapa, Putera, dan Roh Kudus yang merupakan keluarga Allah yang terus mencipta, menguduskan, dan mengampuni yang dijalankan dengan penuh kesetiaan bersama Kristus dan Gereja-Nya.

\footnotetext{
${ }^{6}$ Ibid., hlm. 173-267.
} 


\section{UPAYA MENGHAYATI SPIRITUALITAS PERKAWINAN}

\subsection{Membangun Relasi Komunikasi dalam Perkawinan dan Hidup Keluarga}

Dalam membangun hidup keluarga, suami-istri harus membangun kesaksian hidup, menjadi sakramen tanda keselamatan dan menghadirkan Kerajaan Allah. Dalam hidup berkeluarga perlu diciptakan damai, sukacita, pengampunan, cinta kasih, rela berkurban. Berkat sakramen perkawinan suami-istri menunaikan tugas dan kewajiban mereka sebagai suami-istri dalam keluarga yang diresapi oleh Roh Kristus yang memenuhi mereka dengan iman, harap, dan kasih. Dengan demikian mereka semakin maju berlangkah menuju kesucian dan kesempurnaan, serta saling menguduskan dan karena itu bersama-sama berperan serta demi kemuliaan Allah Bapa. Inilah tindakan membangun spiritualitas perkawinan. Akan tetapi ada banyak rintangan yang menghadang suami-istri untuk berlangkah menuju kesucian.

Pada awal perkawinan biasanya suami-istri saling membahagiakan dan menomorsatukan pasangan seperti yang dilakukan pada masa pacaran. Masa ini disebut masa penyesuaian dan sekaligus masa romans bagi pasangan. Akan tetapi kenyataan situasi ini tidak langgeng. Ketika anak sudah lahir perhatian mulai terbagi. Ibu sibuk merawat anak dan mengurus rumah tangga. Ayah sibuk membanting tulang mengurus kebutuhan keluarga dan menangani tugas-tugas sesuai profesi yang diemban. Hal-hal rutin tersebut cukup menggangu relasi pasangan suami istri. Relasi yang dulu dirasakan dekat, akrab, intim berkat komunikasi yang diliputi cinta yang hangat dan menggairahkan kini mulai terasa hambar. Inilah awal masa kekecewaan. Suami-istri mulai hidup dalam dunianya sendiri. Komunikasi jarang dilakukan. Salah paham sering menjadi pertengkaran dan kadang-kadang masing-masingnya hanya berdiam diri. Pada saat seperti ini perlu diambil tindakan penyelamatan. Suami-istri perlu sadar untuk membangun relasi komunikasi.

Komunikasi dalam hidup keluarga adalah suatu proses tindakan antara dua orang; yang seorang memberi informasi dan yang lain menerima informasi sehingga terjadi kesatuan pemahaman. Syarat utama untuk terpenuhinya komunikasi adalah yang satu mau berbicara dan berani terbuka sedangkan yang lain bersedia dan mau mendengarkan.

Agar komunikasi bisa berlangsung, pertama-tama perlu diusahakan adalah menciptakan suasana yang mendukung proses berlangsungnya relasi komunikasi tersebut.

Untuk itu diperlukan pemahaman terhadap beberapa hal berikut.

(1) Relasi suami-istri harus dinomorsatukan seperti, mau memperhatikan, mengutamakan pasangan, sediakan waktu, mendengarkan dengan hati, rela dan ikhlas menerima; relasi pasangan lebih penting daripada prestasi.

(2) Cinta itu lebih dari sekadar perasaan karena perasaan itu selalu berubah-ubah. Cinta itu adalah keputusan untuk tetap setia dalam suka-duka, dalam untungmalang, juga ketika kehangatan pasangan mulai pudar, saling menerima apa adanya dan bukan ada apanya. Saling membantu untuk berkembang menemukan pribadi yang sejati.

(3) Tugas istri adalah menciptakan suasana yang enak di rumah sehingga suami dan anak-anak merasa kerasan dan betah di rumah. Suami harus memberi rasa nyaman, perlindungan, perhatian, dan kemesraan pada istri dan anak-anaknya. Jadi ada hubungan timbal balik. 
(4) Masalah keluarga harus didialogkan bersama untuk mencapai mufakat dan saling pengertian. Masalah seperti uang, mertua, pendidikan anak, suku, hobi terkadang menjadi unsur pertengkaran.

(5) Diadakan doa bersama, terutama merayakan Misa atau Ekaristi bersama di gereja, untuk bersyukur kepada Tuhan atas segala berkat, ataupun segala kekurangan, mohon berkat hidup keluarga selanjutnya.

(6) Dalam berkomunikasi khususnya menyangkut hal-hal yang peka, hendaknya lebih banyak dipakai kata: saya dan bukan kau. Maksudnya supaya lebih mengutamakan perasaan sendiri dan bukan menuduh pasangan. Hendaklah katakata: selalu, tak pernah, memang kau begitu, dan sebagainya, jangan dipakai.

(7) Komunikasi untuk membangun relasi merupakan cita-cita untuk saling membahagiakan dalam hidup perkawinan. Karena dengan membangun relasi komunikasi pasangan akan saling membahagiakan. Itulah tujuan perkawinan dalam perjalanan menuju kesucian.

Demikianlah beberapa hal yang perlu diperhatikan untuk membangun relasi komunikasi dalam hidup perkawinan dan hidup berkeluarga.

\subsection{Beberapa Cara Mengawetkan Relasi Komunikasi}

Hidup berkeluarga merupakan suatu perjalanan menuju kesucian. Dan seluruh hidup perlu disucikan. Karena suami-istri telah disucikan dalam Sakramen, maka seluruh perbuatan yang bertujuan untuk meningkatkan dan mengakrabkan kehidupan keluarga serta semua pekerjaan yang tampak sepele ikut diangkat menjadi suci dan luhur. Bekerja mencari nafkah bagi keluarga itu lebih daripada hanya perbuatan ekonomis belaka. Sebab dalam iman juga menampakkan tanggung jawab manusia terhadap anugerah Tuhan yang telah berfirman, "Kuasailah dunia dan taklukkanlah."

Mengatur ekonomi rumah tangga secara baik tidak hanya perlu untuk menjaga dan menjamin kesejahteraan keluarga, tetapi juga bertanggung jawab terhadap Tuhan dan memuliakan Allah. Demikianlah prokreasi atau persetubuhan atau intimitas di satu pihak adalah perbuatan biologis manusiawi sebagai penyerahan diri secara total atau untuk memuaskan gairah seksual, namun dalam iman kristiani menjadi perbuatan yang suci dan mulia karena mengungkapkan pasrah diri secara menyeluruh antara Kristus dan GerejaNya. Jadi hal yang suci ini harus dijaga kemurniannya dan tidak boleh disalahgunakan (bdk. Ef 5; 22-35).

Perkawinan kristiani sebagai suatu sakramen hanya dapat dihayati oleh pasangan yang sama imannya. Karena dalam iman yang sama itulah suami-istri dan keluarganya akan senantiasa berupaya membangun relasi sakramental dalam berbagai tindakan dan perbuatannya termasuk relasi komunikasi yang dipakai untuk memurnikan perjalanan hidup perkawinan dan hidup keluarga. Karena cita-cita setiap pasangan dalam membentuk keluarga bahagia dan sejahtera saling membahagiakan satu terhadap yang lain. Akan tetapi banyak keluarga kecewa, gagal mewujudkan cita-cita tersebut. Mereka belum siap atau disiapkan secara kurang baik untuk menghadapi berbagai tantangan yang muncul melalui media sosial baik media cetak maupun media elektronik atau bacaan-bacaan lainnya. Demikan pula pengaruh gaya hidup hedonisme, materialisme dan lain-lainnya yang berdampak pada kehidupan perkawinan. Dunia dan peradabannya terus berubah dengan cepat yang sering tidak mendukung dan mempengaruhi perkawinan dan hidup keluarga yang sehat dan murni serta berkualitas baik. 
Oleh karena itu salah satu tugas Gereja adalah secara tetap dan terus-menerus mendampingi para pasangan muda yang ingin menikah atau pasangan yang sudah menikah bahkan pasang-pasangan lansia agar senantiasa menata perjalanan hidup perkawinan menuju kemurnian atau kesucian. Untuk itu disajikan beberapa unsur komunikasi yang secara teknis dapat dipakai untuk relasi komunikasi dalam perkawinan dan hidup keluarga.

(1) Sharing atau berbagi perasaan serta pengalaman. Ini merupakan satu cara untuk membebaskan diri dengan berbagi melalui tuturan. Setiap anggota kelompok yang melakukan sharing harus saling mendengarkan. Perlu disadari bahwa ini bukan diskusi sehingga tidak perlu ditanggapi atau dikomentari peserta lain. Hal ini membutuhkan latihan agar mendapat sharing yang berkualitas. Juga sebaiknya dilakukan oleh kelompok yang setara atau sepaguyuban. Di dalam kehidupan berkeluarga dapat dilakukan sharing bersama putera putri yang sudah matang atau dewasa. Mereka dapat memberi masukan yang bermanfaat bagi bapak-ibunya dalam menata perjalanan hidup perkawinannya.

(2) Cara lain adalah diskusi atau komunikasi dari 'kepala ke kepala. Hal ini disebut pula bertukar pikiran. Karena setiap pasangan memiliki gaya kepribadian (personality style) yang berbeda juga jenjang pendidikan dan pengalaman yang sangat berbeda maka ada beberapa yang perlu diperhatikan ketika berdiskusi. Jangan menuduh atau mempersalahkan, jangan menggurui, jangan mau menang sendiri. Perbedaan pendapat itu baik untuk memperkaya wawasan berpikir. Perbedaan pendapat adalah teman berpikir.

(3) Berdialog atau komunikasi dari hati ke hati. Inilah cara yang sangat dianjurkan bagi pasangan suami-istri atau bapak-ibu yang telah menikah. Dalam dialog setiap pasangan saling mengungkapkan isi hati dan perasaannya atas dasar saling percaya dan bukan adu pendapat. Perasaan seseorang dalam berdialog tak dapat dipersalahkan. Mengungkapkan perasaan itu tidak mudah, terutama perasaan negatif, seperti kecewa, sedih, sakit hati, dendam, atau perasaan yang kurang menyenangkan misalnya, takut, minder, malu. Perasaan negatif yang dipendam akan jadi beban dan pada suatu saat akan meledak dalam bentuk kemarahan, katakata pedas yang menyakitkan pasangan. Perasaan yang diungkapkan itu merupakan ungkapan jati diri yang sebenarnya. Ini perlu dikomunikasikan dengan komunikasi dari hati ke hati sehingga mempererat relasi dengan pasangan.

(4) Berkomunikasi dengan badan atau sentuhan fisik yakni komunikasi non-verbal tanpa kata-kata. Ini merupakan ungkapan cinta, perhatian, kasih sayang, seperti pandangan mata, senyuman, belaian, rangkulan, dekapan, ciuman, bergandengan tangan. Ini untuk menunjukkan suasana akrab seperti yang dilakukan oleh para sahabat atau orang tua terhadap anaknya.

(5) Komunikasi dengan Tuhan dapat dilakukan dengan (a) doa pribadi bagi pasangan dan doa pasangan bagi anak-anaknya, (b) doa bersama dalam persekutuan doa, (c) doa dengan menggunakan Kitab suci, (d) doa-doa lain seperti novena kepada Hati Kudus, Tiga Salam Maria, Doa Koronka, dan doa-doa lainnya yang naskahnaskahnya cukup banyak tersedia. Paus Yohanes Paulus II menulis dalam Familiaris Concortio sebagai berikut: "Doa keluarga memiliki cirinya sendiri. Doa itu dipanjatkan bersama-sama; suami-istri bersama-sama, orang tua dan anakanak bersama-sama. Persekutuan dalam doa sekaligus merupakan konsekuensi dan persyaratan persekutuan yang dikurniakan melalui sakramen Baptis dan sakramen Perkawinan. Kata-kata yang mengungkapkan janji Tuhan Yesus bahwa Ia akan hadir dapat diterapkan pada para anggota keluarga Kristen secara khas. 
"Aku berkata kepadamu: Jika dua orang daripadamu didunia sepakat meminta apapun juga, permintaan mereka itu akan dikabulkan oleh Bapa-Ku yang di surga. Sebab di mana dua atau tiga orang berkumpul dalam nama-Ku, di situ Aku ada di tengah-tengah mereka (Mat 18: 19-20). Bahan khusus bagi doa keluarga ialah kehidupan keluarga itu sendiri, yang dalam situasinya silih berganti dipandang sebagai panggilan dari Allah dan dihayati sebagai tanggapan manusia selaku putera dan puteri-Nya terhadap panggilan-Nya. Suka maupun duka, harapan dan kekecewaan, kelahiran anak dan ulang tahun, ulang tahun pernikahan orang tua, keberangkatan, perpisahan dan pulangnya anggota, keputusan-keputusan yang penting dan berjangkauan jauh, kematian orang yang sangat dicintai, dan sebagainya, semuanya itu menandai campur tangan Allah yang penuh kasih dalam riwayat keluarga. Hendaklah peristiwa-peristiwa itu dianggap sebagai saat-saat yang cocok untuk bersyukur kepada Allah, memohon sesuatu, untuk penyerahan keluarga penuh kepercayaan ke dalam tangan Bapa mereka bersama di surga. Martabat serta tanggung jawab keluarga Kristen selaku 'Gereja rumah tangga' hanyalah dapat terwujudkan berkat bantuan Allah yang tidak pernah berhenti, yang pasti akan diberikan bila dimohon dengan rendah hati dan penuh kepercayaan dalam doa." (Eminyan 2001: 221-222).

(6) Komunikasi seksualitas yang bersifat sakramental

Kegiatan biologis ini merupakan komunikasi yang paling intim dalam relasi komunikasi suami-istri sehingga sering disebut intimitas. Inilah pengungkapan yang menjadi wujud nyata kesatuan jiwa badan sehingga disebut seksualitas sakramental. Jadi bukan kepuasan biologis semata. Sebab seksualitas sakramental adalalah cara menghayati relasi komunikasi dengan memberi hidup satu sama lain, membuang egoisme, mengikuti teladan Kristus yang memberi diri-Nya bagi manusia. Perkawinan sebagai sakramen hanya dapat dihayati dalam iman, harap, dan kasih akan Kristus dan Gereja-Nya. Bila ketiga hal ini hilang terhadap Tuhan maka kerukunan dalam keluarga mulai pudar bahkan musnah dan terjadi tragedi perceraian.

Oleh karena itu prokreasi atau komunikasi seks bukanlah pertama suatu kegiatan yang dilakukan suami-istri secara biologis melainkan suatu bahasa komunikasi untuk lebih mempersatukan suami-istri dalam kasih mesra, yang menghidupkan dan menyelamatkan. Relasi seksual adalah relasi yang bersifat psikologis, emosional, dan spiritual. Dengan demikian relasi seksual perlu dibingkai dengan cinta dan kedekatan agar hubungan tersebut membahagiakan. Untuk itu suami-istri perlu memperhatikan hal-hal berikut.

Pertama, soal waktu pada saat melakukan intimitas. Yang perlu diingat bahwa komunikasi seks dilakukan oleh pria dan wanita yang memiliki pola atau irama yang berbeda. Pola dasar pria adalah cepat dibangkitkan hasrat seksualnya untuk bisa mencapai orgasme. Sebaliknya, wanita membutuhkan waktu yang lama untuk mencapai orgasme. Kedua adalah tempat. Wanita membutuhkan rangkulan atau sentuhan pada tempat yang erotik bagi wanita seperti mencium bibir, payudara, membelai vagina dan klitoris agar istri merasa siap untuk melakukan intimitas.

Suami-istri yang melakukan relasi seksual yang bersifat sakramental perlu memperhatikan pula kedua hal tersebut di atas. Dan ketiga perlu pula diketahui bahwa ada dua jenis pengalaman relasi seksual yang normal bagi pasangan suamiistri yakni hubungan seks yang melibatkan penis dan vagina dan interstimulasi 
seksual karena dalam setiap perkawinan pasti ada waktu tertentu pasangan suamiistri melalukan pantangan untuk melakukan hubungan.Tentang hal ini hanya suami-istrilah yang mengetahui waktunya.

Perkawinan katolik bersifat sakramental. Ini berarti pasangan suami-istri yang saling memberikan sakramen. Dengan demikian tindakan intimitas adalah tindakan pemurnian sakramen perkawinan. Sebab dengan melakukan prokreasi yang penuh cinta, hidup dan keselamatan pasangan suami-istri dan anak-anaknya yang dilahirkan oleh mereka membentuk Gereja domestik yang setia berjalan menuju kesucian untuk pemurnian kehidupan perkawinan dalam kasih Kristus dan Gereja-Nya.

Beberapa hal yang dikemukakan di atas adalah hal-hal yang sangat khusus untuk dibicarakan kepada para calon pengantin atau peserta kursus persiapan perkawinan. Oleh sebab itu para pendamping peserta kursus perlu mempersiapkan diri dan meminta petunjuk dari Pembina Pastoral Keluarga atau Komisi Pastoral keluarga untuk menyajikan dan menjelaskan secara tepat dan benar khususnya hal yang berkaitan dengan relasi seksual sakramental.

\section{PENUTUP}

Seluruh hidup perkawinan katolik adalah sakramen. Perbuatan-perbuatan yang dilakukan sekecil apapun, jika dilakukan dengan iman akan kasih Tuhan untuk meningkatkan dan mengakrabkan kehidupan keluarga dapat diangkat menjadi suci dan luhur. Mencari nafkah walaupun hasilnya tak seberapa, mengurus ekonomi rumah tangga meskipun dianggap sepele jika dijalankan karena itu adalah anugerah Tuhan yang dilakukan oleh suami-istri atas dasar iman maka hasilnya akan menyucikan perkawinan mereka.

Allah sang Pencipta telah menciptakan manusia berpasangan sebagai pria dan wanita. Keduanya diciptakan untuk saling mencintai, menjadi gambar Allah diciptakan mereka. Keduanya menjadi mitra Allah sebagai prokreator dan memanfaatkan lingkungan hidupnya untuk mensejahterakan hidup mereka. Semua perbuatan yang dilakukan oleh manusia merupakan kehendak Allah sendiri sehingga perlu dilakukan atas dasar iman akan kasih karunia Tuhan. Sebab itu kehidupan suami-istri perlu disucikan melalui sakramen Perkawinan. Kristus mengangkat atau menjadikan hidup perkawinan sebagai sakramen untuk mewartakan Kerajaan Allah.

Kabar Gembira yang diwartakan dalam Kitab Suci, amanat Kritus melalui para Rasul dan Bapa-Bapa Gereja, yang dilanjutkan oleh para Pemimpin Gereja Universal dan Lokal adalah amanat Kristus sendiri bagi kelanjutan hidup Gereja-Nya. Karena itu Kristus sendiri menghadirkan Roh Kudus menjadi Penghibur sekaligus Penolong dalam seluruh tindakan yang dilakukan oleh Gereja. Allah Tritunggal Kudus, melalui Kristus Yesus memanggil manusia khususnya keluarga Gereja Katolik menampakkan cinta kasih hidup mereka agar dunia sekitarnya percaya bahwa Allah begitu mencintai manusia sehingga mengutus Putera-Nya Tunggal untuk menyelamatkan mereka dari dosa dan maut. Dan bahwa keluarga kristiani perlu menjadikan hidupnya semakin berkualitas dalam menghayati cintanya untuk meneruskan kehidupan melalui anak-anaknya yang merupakan kasih karunia Allah bagi mereka. Cinta kasih timbal balik suami-istri memberikan sumbangan bagi pembangunan Gereja domestik yang sekaligus memberikan sumbangan bagi Gereja universal. 
Hal-hal tersebut di atas dapat dilakukan melalui upaya peningkatan penghayatan spiritualitas perkawinan mereka. Karena dewasa ini kenyataan menunjukkan bahwa krisis nilai sudah mengancam kehidupan manusia khususnya kehidupan perkawinan dan keluarga. Nilai-nilai persaudaraan, toleransi, dan nilai-nilai luhur lainnya perlu terus dikembangkan dalam seluruh kehidupan keluarga agar menjadi terang bagi bangsa-bangsa dan suku-suku bangsa yang sedang mengalami krisis nilai luhur dalam kehidupan mereka.

Dengan demikian tujuan umum dari tulisan ini untuk mengajak, memotivasi para katekis dan fungsionaris pastoral, serta para imam dan klerus untuk terus membantu mendampingi keluarga-keluarga kristiani dalam menjalankan peran dan fungsinya sebagai imam, nabi, dan raja bagi dirinya dan bagi umat Allah seluruhnya agar dapat mengurangi krisis nilai-nilai luhur dalam perkawinan dan hidup keluarga kristiani.

\section{Daftar Kepustakaan}

\section{Dokumen Gereja}

Konsili Vatikan II, Gaudium et Spes, Hardawiryana (Penerj.) Jakarta: Obor, 1993.

Yohanes Paulus II, Familiaris Consortio, Anjuran Apostolik tentang Peranan Keluarga Kristiani dalam Dunia Modern, 1981

\section{Buku-buku}

Eminyan, Maurice, Teologi Keluarga, diterjemahkan dari buku Theology of the Family oleh J. Hadiwiratno MSF, Pustaka Teologi, Penerbit Kanisius, Yogyakarta, 2001

Alkitab Deuterokanonika, LAI- LBI, Jakarta, 1976

Udjan, Djuang Tarsisius, Himpunan Materi Kursus Pendampingan Perkawian, (Manuskrip), untuk keperluan sendiri, Paskel Paroki St. Yosef Onekore, 2010

\section{$\underline{\text { Majalah-informasi }}$}

Catholic Life, Yayasan Pasintera Nusantara, Edisi Pebruari 2019, Jakarta.

Relasi, Majalah Nasional Marriage Encounter Indonesia, Edisi Juni - Agustus 2013 Jakarta. 